\title{
A Sulfate Susceptibility Test for Portland Cements
}

\author{
By W. C. Taylor ${ }^{1}$ and R. H. Bogue ${ }^{2}$
}

\begin{abstract}
A procedure has been developed by means of which portland cements may be given ratings indicative of their resistivity to chemical attack by sulfate-containing solutions. The test, which may be performed in about a day, reveals the intrinsic resistivity to such attack by the cement itself as contrasted with the usual performance tests on mortar or concrete specimens, which require periods of weeks or months. The method involves the measurement of the amount of dissolved $\mathrm{SO}_{3}$ rendered insoluble when cement is shaken with limewater for a stated period. The test has been examined critically and extensive correlations made with performance tests on laboratory and commercial portland cements.
\end{abstract}

\section{Introduction}

It has long been recognized $[3]^{3}$ that the resistivity of concrete structures to attack by sulfate waters is a function of both chemical and physical factors. Thus the cement paste may contain materials that are reactive with sulfate solutions, but the life of the concrete structure exposed to such solutions will be affected by other factors than the composition of the paste. It will be prolonged by any device that will give greater impermeability or greater constancy of volume to the hydrating member and shortened by the use of lean mixes and the presence of volume-expansive constituents.

The principal chemical cause of the disintegration of concrete in sulfate waters has been shown $[2,5$, $13,15]$ to be associated with a reaction between the sulfate ions of the solution, in the presence of calcrum hydroxide, and the alumina-containing phases of the cement that dissolve in the solution. It has been observed [4] that crystalline tricalcium aluminate is less resistant to attack in sulfate solutions than is the same composition in the glassy state, whereas crystalline tetracalcium alumino ferrite (or the iron-phase solid solution) is more resistant to such attack than its glassy counterpart. Also it has been noted that alumina in the form of the tricalcium aluminate is less resistant to attack in sulfate solutions than it is when in the form of the tetracalcium alumino ferrite. No reason has been advanced for the apparently anomalous behavior of the tricalcium aluminate.

Calcium sulfate and tricalcium aluminate, in the presence of calcium hydroxide (always present in cement pastes owing to the hydrolysis of tricalcium silicate) react to form calcium sulfoaluminate [11]. Under the conditions of the test, the high-sulfate form is produced according to the equation:

$$
\begin{gathered}
3 \mathrm{CaSO}_{4}+3 \mathrm{CaO} \cdot \mathrm{Al}_{2} \mathrm{O}_{3}+31 \mathrm{H}_{2} \mathrm{O}= \\
3 \mathrm{CaO} \cdot \mathrm{Al}_{2} \mathrm{O}_{3} \cdot 3 \mathrm{CaSO}_{4} \cdot 31 \mathrm{H}_{2} \mathrm{O} .
\end{gathered}
$$

If we assume a constant $\mathrm{SO}_{3}$ concentration in the solution, the rate and extent of the above reaction will increase with the amount of alumina that enters the solution in any given period of time. Since, however, this amount varies with the state of the tricalcium aluminate and is also affected by the presence of crystalline or glassy iron-alumina solid solutions, the reaction cannot be defined by a mere proportionality factor applied to the $\mathrm{Al}_{2} \mathrm{O}_{3}$ or $3 \mathrm{CaO} \cdot \mathrm{Al}_{2} \mathrm{O}_{3}$ present.

The usual method for evaluating the resistivity of cements to sulfate attack has been to note the behavior (change in length, strength, sonic modulus, appearance, etc.) of mortar or concrete specimens when placed for extended periods in natural or synthetic sulfate solutions. The time element, however, militates against such tests for specification purposes. Furthermore, these tests measure the total capacity of the specimen to withstand attack rather than the inherent resistivity of the cement. For these reasons they are not ideally designed for the purpose of indicating the sulfate resistivity of cements.

An investigation initiated in this laboratory in 1941 has resulted in a method by which the progress of the above reaction may be noted. In principle, it consists of a measurement of the amount of dissolved $\mathrm{SO}_{3}$ rendered insoluble by reaction with aluminates when cement is shaken with limewater for a stated period of time. In the treatment that follows, the adopted procedure will first be given, followed by a discussion of critical aspects of the test and correlations obtained between the test and other methods of evaluating sulfate resistivity.

\section{Test Procedure}

The $\mathrm{SO}_{3}$ content of the cement to be tested is first determined by any acceptable procedure [1].

About $30 \mathrm{~g}$ of standard Ottawa sand, or some similar silica sand, is placed in a dry 100 -ml graduated cylinder, so designed that it can be fitted with a stopper. (A blank determination should be made with each lot of sand employed.) A sample of cement is weighed out equal in grams to 5.4 divided by the percentage of $\mathrm{SO}_{3}$ in the cement. This sample is placed in the cylinder containing the sand. One hundred milliliters of saturated limewater is measured in a $100-\mathrm{ml}$ pipette and added rapidly to the cylinder by inverting the pipette. A clean rub.

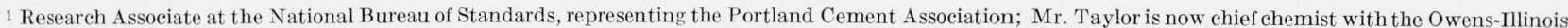
Glass Co.

2 Director of the Portland Cement Association Fellowship at the National Bureau of Standards.

3 Figures in brackets indicate the literature references at the end of this paper. 
ber stopper is inserted and the mixture at once shaken vigorously by hand. The cylinder is then fastened to a rotary shaker that is operated at a rate of $60 \mathrm{rpm}$ for $6 \mathrm{hr}$ from the time of the addition of the limewater. (The rack should be so designed that no cylinder is more than 6 in. from the hub.) In order to obtain consistent results within a laboratory or between different laboratories, it is essential that the test be performed at a constant temperature.

Just before the end of the 6 -hr reaction period, a 9 -cm No. 42 filter paper (or a comparable paper) is inserted in a Buchner funnel and moistened with distilled water. Suction is applied, and the contents of the cylinder are poured into the funnel. The cylinder is washed with 50 to $60 \mathrm{ml}$ of distilled water and the washings poured onto the funnel. This step is repeated once.

The filtrate is transferred to a $600-\mathrm{ml}$ beaker. The filter flask is twice washed with 50 to $60 \mathrm{ml}$ of distilled water and the washings added to the filtrate. The volume is then made up to about $350 \mathrm{ml}, 5 \mathrm{ml}$ of concentrated $\mathrm{HCl}$ added, and the weight of $\mathrm{SO}_{3}$ determined by precipitation with $\mathrm{BaCl}_{2}$ solution in accordance with standard procedure [1].

After the amount of $\mathrm{SO}_{3}$ remaining in the solution is determined, that value is subtracted from the amount of $\mathrm{SO}_{3}$ that was present in the sample of the cement taken. This difference is assumed to be the quantity of $\mathrm{SO}_{3}$ that has reacted to form calcium sulfoaluminate during the period of the test. This is calculated as percentage of the $\mathrm{SO}_{3}$ originally present in the cement and is designated as the "sulfate reaction value". 'These values are reported to the nearest whole number.

\section{Critical Aspects of the Test}

\section{Source of Sulfate}

There would seem to be an advantage if an excess of $\mathrm{SO}_{3}$ could be provided for interaction with the aluminates, but no satisfactory means for accomplishing that has been found.

An attempt to use sodium sulfate for this purpose gave erratic results, and the differentiation between resistant and nonresistant cements was not satisfactory. This is believed to have been due to a reaction between the sodium sulfate and calcium hydroxide by which gypsum was precipitated. In such case, the change in $\mathrm{SO}_{3}$ concentration of the solution would not be a measure solely of the interaction of $\mathrm{SO}_{3}$ with the aluminates.

If gypsum is to be the source of the $\mathrm{SO}_{3}$, it is obvious that the amount present must be such that it will dissolve completely in the solution used. For, if gypsum were present in excess of that amount, then, as $\mathrm{SO}_{3}$ was removed from the solution by the reaction with the aluminates, more $\mathrm{SO}_{3}$ would enter the solution from the gypsum, and the progress of the reaction would not be measured by the $\mathrm{SO}_{3}$ concentration of the resulting solution. An amount of cement must therefore be taken such that its content of gypsum (or other form of calcium sulfate) will be completely dissolved. And, since a cement paste is quickly saturated with $\mathrm{Ca}(\mathrm{OH})_{2}$ due to the hydrolysis of $3 \mathrm{CaO} \cdot \mathrm{SiO}_{2}$, it appears proper that the solvent be saturated limewater.

\section{Solubility of Calcium Sulfate and Sulfoaluminate}

According to Cameron and Bell [6], $\mathrm{Ca}(\mathrm{OH})_{2}$ and $\mathrm{CaSO}_{4} .2 \mathrm{H}_{2} \mathrm{O}$ can coexist as solid phases in equilibrium with a solution containing $1.588 \mathrm{~g}$ of $\mathrm{CaSO}_{4}$ and $1.222 \mathrm{~g}$ of $\mathrm{CaO}$ per liter at $25^{\circ} \mathrm{C}$. This means that $0.0934 \mathrm{~g}$ of $\mathrm{SO}_{3}$ from gypsum (equivalent to $0.2008 \mathrm{~g}$ of $\mathrm{CaSO}_{4} \cdot 2 \mathrm{H}_{2} \mathrm{O}$ or $0.1588 \mathrm{~g}$ of $\mathrm{CaSO}_{4}$ ) may be dissolved in $100 \mathrm{ml}$ of saturated limewater at $25^{\circ} \mathrm{C}$. In a more recent report by Hansen and Pressler [8], it was found that 0.0123 mole/liter of $\mathrm{SO}_{3}$ can dissolve from gypsum in a saturated solution of $\mathrm{Ca}(\mathrm{OH})_{2}$ at $25^{\circ} \mathrm{C}$. This means that $0.0985 \mathrm{~g}$ of $\mathrm{SO}_{3}$ from gypsum (equivalent to $0.2118 \mathrm{~g}$ of $\mathrm{CaSO}_{4} \cdot 2 \mathrm{H}_{2} \mathrm{O}$ or $0.1674 \mathrm{~g}$ of $\mathrm{CaSO}_{4}$ ) may be dissolved in 100 $\mathrm{ml}$ of saturated limewater at $25^{\circ} \mathrm{C}$. Hansen and Pressler show also that the solubility of the gypsum in the saturated limewater increases rapidly with increasing amounts of $\mathrm{KOH}$ or $\mathrm{NaOH}$ in the solution.

The solubility of the calcium sulfoaluminate in saturated limewater is so small as to be practically insignificant in the test; i. e. about 0.005 percent [10].

\section{The $\mathrm{SO}_{3}$ Limit}

From these data it appeared that the method would rest on safe ground by fixing the upper limit of $\mathrm{SO}_{3}$ allowed to be present at $0.09 \mathrm{~g} / 100 \mathrm{ml}$, equivalent to a gypsum limit of $0.19 \mathrm{~g} / 100 \mathrm{ml}$ of saturated lime solution. Assuming the use of $3 \mathrm{~g}$ of cement with $100 \mathrm{ml}$ of solution, the $0.09 \mathrm{~g}$ of $\mathrm{SO}_{3}$ limit would be equivalent to an $\mathrm{SO}_{3}$ concentration in the cement of 3 percent, which is sufficiently high to provide for any cement passing present ASTM specifications.

It is necessary, however, to consider the effect on the sulfate reaction value of a variation in the $\mathrm{SO}_{3}$ content of cements. An examination of more than a hundred commercial cements analyzed in 1945 shows a range in $\mathrm{SO}_{3}$ from 1.1 to 2.2 percent. Seventyfive percent of these cements fall within the range of 1.6 to 1.9 percent of $\mathrm{SO}_{3}$. The 106 cements reported by Miller and Manson [13] in 1940 show a range (excepting one clinker) of 1.3 to 2.6 percent of $\mathrm{SO}_{3}$, of which 74 percent fall between 1.6 and 1.9 percent of $\mathrm{SO}_{3}$.

Two ways of providing a constant $\mathrm{SO}_{3}$ content in the test samples were considered. The more direct method would be to add gypsum in such amount as to provide the upper limit allowable (in order to include all cements). That would be equivalent to 3.0 percent of $\mathrm{SO}_{3}$. It has been observed, however, that the sulfate resistivity of a cement may be improved by certain increases in its $\mathrm{SO}_{3}$ content [5]. Hence this arbitrary addition might change the sulfate resistivity and so give fictitious values. The other method would be to take an amount of sample such that the $\mathrm{SO}_{3}$ content would be equal to that in $3 \mathrm{~g}$ of a cement containing 1.8 percent of $\mathrm{SO}_{3}$ (an 
average value). In other words, the weight in grams of cement to be taken should equal 5.4 divided by the percentage of $\mathrm{SO}_{3}$ in the cement.

\section{Availability of Calcium Sulfate}

Since anhydrite $\left(\mathrm{CaSO}_{4}\right)$ and plaster of Paris $\left(\mathrm{CaSO}_{4} \cdot \frac{1}{2} \mathrm{H}_{2} \mathrm{O}\right)$ are sometimes present with the gypsum $\left(\mathrm{CaSO}_{4} \cdot 2 \mathrm{H}_{2} \mathrm{O}\right)$ added to control the setting time of cements, it was necessary to examine their relative solubilities in saturated limewater. Pure specimens of natural anhydrite and gypsum, and hemihydrate prepared from the gypsum, were ground to three size fractions. Samples containing $0.09 \mathrm{~g}$ of $\mathrm{SO}_{3}$ were shaken in $100-\mathrm{ml}$ portions of limewater for different periods of time at about $70^{\circ} \mathrm{F}$, and the percentage of the $\mathrm{SO}_{3}$ in solution was then determined. The results are shown below.

It is seen that gypsum and hemihydrate dissolved completely in $1 \mathrm{hr}$, but the anhydrite was much more slowly soluble. In $6 \mathrm{hr}$ the finest fraction was only two-thirds dissolved.

In order to ascertain if this relatively slow solubility of anhydrite might affect the usefulness of the test, a series of cements was examined. A number of commercial clinkers were ground to two orders of specific surface (about 1,800 and $2,550 \mathrm{~cm}^{2} / \mathrm{g}$ ) in one case with pure gypsum and in another with gypsum in which 10 percent of its $\mathrm{SO}_{3}$ content had been replaced with natural anhydrite. The total $\mathrm{SO}_{3}$ was fixed at 1.7 percent in all cases.

The sulfate reaction values are shown in table 1 , together with the ages of disintegration of 1 by 1 by 6 in. 1:3 mortar bars that had been stored in 10 percent of $\mathrm{Na}_{2} \mathrm{SO}_{4}$ solution after 1 day in the molds and 6 days in water. The amount of the difference in sulfate reaction value due to the presence of the anhydrite is seen to be small in all cases, and usually would be altogether insignificant in establishing the sulfate resistivity of the cement.

Percentage solubility for the screen-size fraction indicated

\begin{tabular}{|c|c|c|c|c|c|c|c|c|c|}
\hline \multirow{2}{*}{ Time of shaking } & \multicolumn{3}{|c|}{ Gypsum } & \multicolumn{3}{|c|}{ Hemihydrate } & \multicolumn{3}{|c|}{ Anhydrite } \\
\hline & $\begin{array}{c}100 \text { to } \\
200\end{array}$ & $\begin{array}{l}200 \text { to } \\
325\end{array}$ & $\begin{array}{c}\text { Minus } \\
325\end{array}$ & $\begin{array}{c}100 \text { to } \\
200\end{array}$ & $\begin{array}{c}200 \text { to } \\
325\end{array}$ & $\begin{array}{c}\text { Minus } \\
325\end{array}$ & $\begin{array}{c}100 \text { to } \\
200\end{array}$ & $\begin{array}{c}200 \text { to } \\
325\end{array}$ & $\begin{array}{c}\text { Minus } \\
325\end{array}$ \\
\hline$h r$ & $\begin{array}{l}\% \\
100 \\
100 \\
100\end{array}$ & $\begin{array}{l}\% \\
100 \\
100 \\
100\end{array}$ & $\begin{array}{l}\% \\
100 \\
100 \\
100\end{array}$ & $\begin{array}{l}\% \\
100 \\
100 \\
100\end{array}$ & $\begin{array}{l}\% \\
100 \\
100 \\
100\end{array}$ & $\begin{array}{l}\% \\
100 \\
100 \\
100\end{array}$ & $\begin{array}{r}\% \\
6.1 \\
11.2 \\
24.2\end{array}$ & $\begin{array}{r}\% \\
7.9 \\
14.2 \\
26.1\end{array}$ & $\begin{array}{l}\% \\
45 . \\
55 . \\
66 .\end{array}$ \\
\hline
\end{tabular}

TABLE 1. Effect of fineness and anhydrite on sulfate reaction values and life of mortar specimens stored in 10-percent $\mathrm{Na}_{2} \mathrm{SO}_{4}$ solution

The cements, prepared from commercial clinkers, contained 1.7-percent total $\mathrm{SO}_{3}$

\begin{tabular}{|c|c|c|c|c|c|}
\hline No. & $\begin{array}{c}\text { Calculated } \\
3 \mathrm{CaO} . \mathrm{Al}_{2} \mathrm{O}_{3}\end{array}$ & $\begin{array}{l}\text { Gypsum } \\
\text { replaced } \\
\text { by natural } \\
\text { an hydrite }\end{array}$ & $\begin{array}{l}\text { Specific } \\
\text { surface }\end{array}$ & $\begin{array}{c}\text { Sulfate } \\
\text { reaction } \\
\text { value }\end{array}$ & $\begin{array}{c}\text { Age at disinte- } \\
\text { gration of } 1 \text { by } 1 \\
\text { by } 6 \text { in. } 1: 3 \text { mor- } \\
\text { tar bars in } 10 \% \\
\mathrm{Na}_{2} \mathrm{SO}_{4}\end{array}$ \\
\hline $419 \begin{array}{l}\mathrm{A} \\
\mathrm{B} \\
\mathrm{C} \\
\mathrm{D}\end{array}$ & $\begin{array}{r}\% \\
2 \\
2 \\
2 \\
2\end{array}$ & $\begin{array}{r}\% \\
0 \\
0 \\
10 \\
10\end{array}$ & $\begin{array}{l}\mathrm{cm}^{2} / \mathrm{g} \\
1,850 \\
2,530 \\
1,795 \\
2,540\end{array}$ & $\begin{array}{l}22 \\
28 \\
25 \\
29\end{array}$ & $\begin{array}{l}\text { Weeks } \\
\text { Good at } 1 \text { yr } \\
\text { Do. } \\
\text { Do. } \\
\text { Do. }\end{array}$ \\
\hline $418 \begin{array}{r}\mathrm{A} \\
\mathrm{B} \\
\mathrm{C} \\
\mathrm{D}\end{array}$ & $\begin{array}{l}4 \\
4 \\
4 \\
4\end{array}$ & $\begin{array}{r}0 \\
0 \\
10 \\
10\end{array}$ & $\begin{array}{l}1,800 \\
2,480 \\
1,800 \\
2,540\end{array}$ & $\begin{array}{l}24 \\
36 \\
26 \\
40\end{array}$ & $\begin{array}{l}\text { Do. } \\
\text { Do. } \\
\text { Do. } \\
\text { Do. }\end{array}$ \\
\hline $417 \begin{array}{l}\mathrm{A} \\
\mathrm{B} \\
\mathrm{C} \\
\mathrm{D}\end{array}$ & $\begin{array}{l}10 \\
10 \\
10 \\
10\end{array}$ & $\begin{array}{r}0 \\
0 \\
10 \\
10\end{array}$ & $\begin{array}{l}1.840 \\
2,510 \\
1,830 \\
2,550\end{array}$ & $\begin{array}{l}49 \\
73 \\
53 \\
65\end{array}$ & $\begin{array}{l}24 \\
16 \\
24 \\
16\end{array}$ \\
\hline $\begin{array}{rl}420 & \mathrm{~A} \\
\mathrm{~B} \\
\mathrm{C} \\
\mathrm{D}\end{array}$ & $\begin{array}{l}9 \\
9 \\
9 \\
9\end{array}$ & $\begin{array}{r}0 \\
0 \\
10 \\
10\end{array}$ & $\begin{array}{l}1,785 \\
2,550 \\
1,795 \\
2,500\end{array}$ & $\begin{array}{l}57 \\
83 \\
55 \\
82\end{array}$ & $\begin{array}{l}19 \\
14 \\
19 \\
17\end{array}$ \\
\hline $421 \begin{array}{r}\mathrm{A} \\
\mathrm{B} \\
\mathrm{C} \\
\mathrm{D}\end{array}$ & $\begin{array}{l}12 \\
12 \\
12 \\
12\end{array}$ & $\begin{array}{r}0 \\
0 \\
10 \\
10\end{array}$ & $\begin{array}{l}1,845 \\
2,550 \\
1,790 \\
2,570\end{array}$ & $\begin{array}{r}84 \\
100 \\
82 \\
99\end{array}$ & $\begin{array}{l}17 \\
12 \\
16 \\
12\end{array}$ \\
\hline $416 \begin{array}{r}\mathrm{A} \\
\mathrm{B} \\
\mathrm{C} \\
\mathrm{D}\end{array}$ & $\begin{array}{l}15 \\
15 \\
15 \\
15\end{array}$ & $\begin{array}{r}0 \\
0 \\
10 \\
10\end{array}$ & $\begin{array}{l}1,830 \\
2,490 \\
1,8: 0 \\
2,475\end{array}$ & $\begin{array}{r}100 \\
99 \\
99 \\
100\end{array}$ & $\begin{array}{r}12 \\
8 \\
8 \\
8\end{array}$ \\
\hline
\end{tabular}

\section{Effect of Specific Surface of Cement}

It will be noted also from table 1 that an increase in the fineness of the cements, of a given composition and anhydrite content, resulted in an increase in the sulfate reaction value. That is, the finer the cement the less resistant it is indicated to be by this test. This indication was confirmed by the relative life of mortar bars of these cements stored in 10-percent solutions of sodium sulfate. Because the correlation is excellent, it can be postulated that the effect of surface area of the cement in the test is reflected in the performance of exposed specimens.

\section{Effect of Temperature and Agitation of Reacting Solutions}

It is to be expected that the rate of the reaction of calcium sulfoaluminate formation will be affected by temperature. The correctness of this supposition is indicated by the following results obtained by Hansen [9] on cements at three temperatures:

\begin{tabular}{c|c|c|c}
\hline \hline \multicolumn{3}{c}{ Sulfate reaction values at temperature indicated } \\
\hline & $\begin{array}{c}\text { Cement } \\
\text { No. 13 }\end{array}$ & $\begin{array}{c}\text { Cement } \\
\text { No. 14 }\end{array}$ & $\begin{array}{c}\text { Cement } \\
\text { No. 12 }\end{array}$ \\
\cline { 2 - 2 } & & & \\
& 61 & 94 & 94 \\
\hline 89 & 66 & 97 & 97 \\
97 & 86 & 97 & 98 \\
\hline
\end{tabular}


The increase in activity with rise in temperature points to the necessity, for comparable results, of carrying out the reactions involved in the test at a constant temperature.

Runs performed with different periods of agitation of the reacting solution showed that the amount of $\mathrm{SO}_{3}$ removed from the solution increased with time of shaking. The $\mathrm{SO}_{3}$ was removed rapidly during the first hour, but after $4 \mathrm{hr}$ the rate of decrease in $\mathrm{SO}_{3}$ concentration of the solution was slow and nearly constant over prolonged periods. It appears, therefore, that the selection of a 6 -hr period serves the purpose of the test.

Changes in the speed of rotation and in the distance of the sample from the axis of rotation, were found also to affect slightly the rate of the reaction, and hence to necessitate the arbitrary fixing of these items in the procedure.

\section{Solubility of Tricalcium Aluminate}

The amount of $\mathrm{SO}_{3}$ in a cement is usually inadequate to react with all of the aluminates that are in the cement. Thus the $\mathrm{SO}_{3}$ in a given quantity of cement containing 1.8 percent of $\mathrm{SO}_{3}$ can react with only 2.02 percent of $3 \mathrm{CaO} \cdot \mathrm{Al}_{2} \mathrm{O}_{3}$. It has been found, however, that the $3 \mathrm{CaO} \cdot \mathrm{Al}_{2} \mathrm{O}_{3}$ goes into solution slowly, the amount entering solution in a given period of time increasing with the concentration of the compound in the cement [10]. Hence it may be observed in the experiments throughout this series that only when the $3 \mathrm{CaO} \cdot \mathrm{Al}_{2} \mathrm{O}_{3}$ is present in amounts many times greater than 2 percent, will the 1.8 percent of $\mathrm{SO}_{3}$ be consumed completely in the period allowed for the test.

The range of differentiation in the test has been so adjusted that positive distinction may be had in the sulfate reaction value from an unreactive cement, at zero on the percentage scale, to a highly reactive cement, at 95 to 100 on the percentage scale.

\section{Reproducibility of Results}

A large number of sulfate resistivity tests have been made on identical cements by different operators in this and other laboratories. An anlysis of the data reveals that it is reasonable to expect an operator to obtain reaction values for a given cement that agree within three points. Similar agreement is obtained between different operators, provided the temperature and procedure are rigorously identical.

Although the technique of the test is simple, care must be used throughout because of the small amounts of $\mathrm{SO}_{3}$ involved. A 3-g sample of cement having an $\mathrm{SO}_{3}$ content of 1.8 percent contains $0.0540 \mathrm{~g}$ of $\mathrm{SO}_{3}$. A difference of $1 \mathrm{mg}$ in the amount of $\mathrm{SO}_{3}$ determined in the filtrate will be responsible for a difference of about two points in the reaction value.

\section{Correlation of the Sulfate Susceptibility Test With Performance Records}

\section{Selected Clinkers}

The 24 cements specially prepared from six commercial clinkers (table 1) showed an excellent correlation between the results obtained with the new test and the durability of 1 by 1 by 6 in. $1: 3$ mortar bars stored in 10-percent sodium sulfate solution. None of the cements that remained sound at $1 \mathrm{yr}$ gave a sulfate-reaction value above 40 , but every cement that distintegrated within that period gave sulfate-reaction values ranging from 49 to 100 .

\section{Laboratory Cements}

A more extensive examination was made with the use of a series of 68 cements prepared in a laboratory kiln from commercial raw materials. Four clinkers were prepared from each of 17 different raw mixtures by varying the heat treatment, indicated as follows:

$S_{1}=$ single-burned clinker slowly cooled,

$S_{2}=$ double-burned clinker slowly cooled,

$r_{\gamma_{1}}=$ single-burned clinker quickly cooled,

$\widehat{\gamma}_{2}=$ double-burned clinker quickly cooled.

The compositions were designed to give a large variation in the potential $3 \mathrm{CaO} \cdot \mathrm{Al}_{2} \mathrm{O}_{3}$ content, and also to give two groups of cements with respect to magnesia content; one group having about 1 percent of $\mathrm{MgO}$ and the other about 5 percent. The resulting clinkers were ground to approximately the same specific surface (about $1,700 \mathrm{~cm}^{2} / \mathrm{g}$ ) with gypsum to give 1.8 percent of $\mathrm{SO}_{3}$ in the cements. From these cements 1 by 1 by 6 in. $1: 2$ mortar bars were moulded and duplicate specimens stored in 2-percent solutions of $\mathrm{MgSO}_{4}$ and $\mathrm{Na}_{2} \mathrm{SO}_{4}$ following 1 day of damp curing and 6 days in water. The length of the bars was measured at stated periods. Sulfate reaction values were determined on all cements.

The linear expansions of the bars at $3 \mathrm{yr}$ and various other data are shown in table 2 , in which the cements are arranged in six groups in order of increasing sulfate reaction value.

An examination of this table will show that the division between definitely resistant and definit sly nonresistant cements is clearly marked by the sulfate reaction values. It will be noted further that no specimen in group 1 , having sulfate reaction values $(S R)$ of 16 to 19 , had a linear expansion greater than 0.200 percent at $3 \mathrm{yr}$. In group 2, $S R 21$ to 34 , the 3-yr expansions with one exception were under 0.300 percent. In group $3, S R 35$ to 50 , the expansions reached as high as 1.026 at $3 \mathrm{yr}$, but in no case had any specimens disintegrated. Three cements fell between $S R 52$ and 54 , one of which 
TABLE 2. Correlation of sulfate reaction values of laboratory cements with length change of 1 by 1 by 6 -inch 1:2 mortar bars stored in 2-percent solutions of $\mathrm{Na}_{2} \mathrm{SO}_{4}$ and $\mathrm{MgSO}_{4}$

Arranged in order of increasing sulfate reaction values

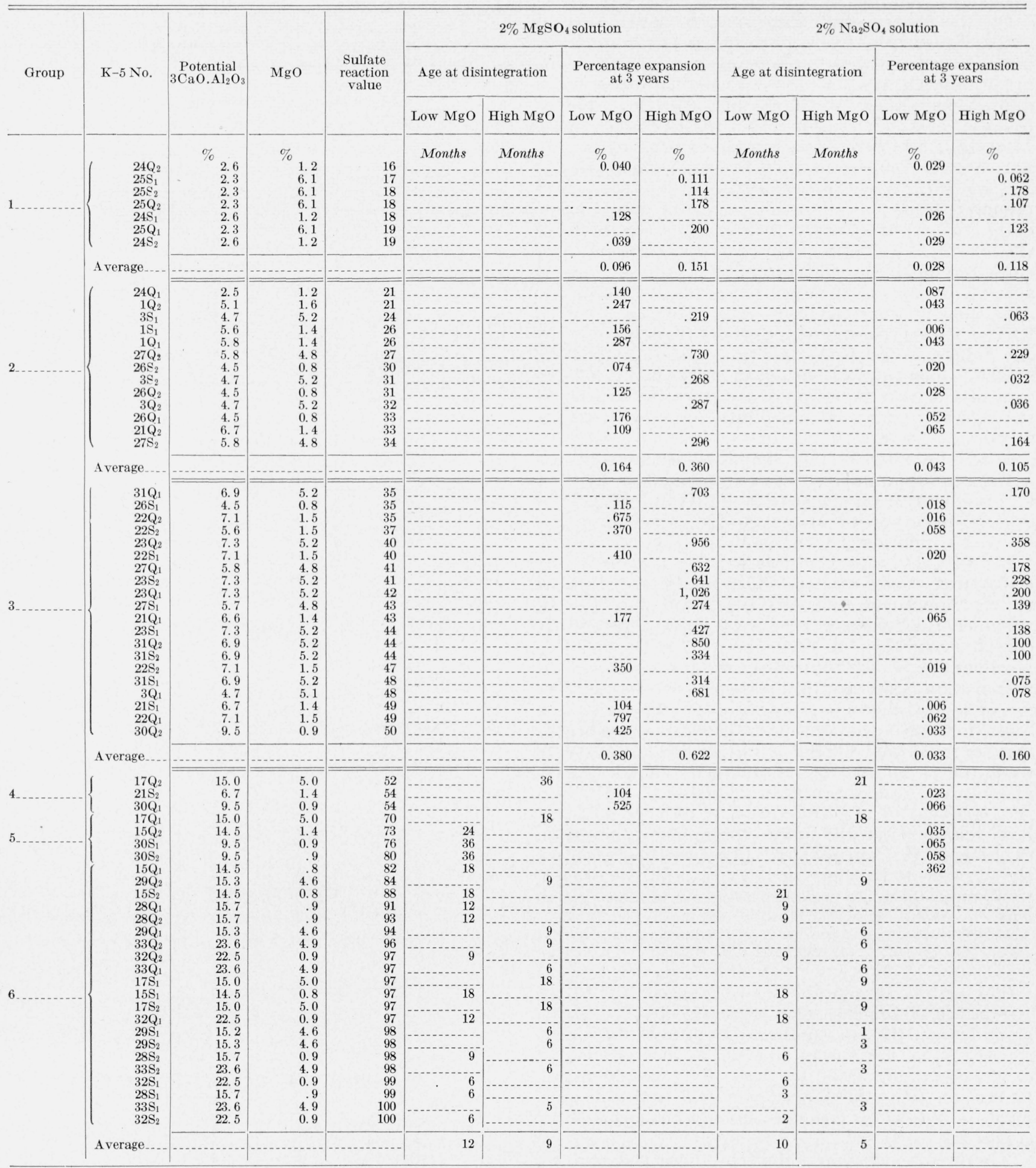


disintegrated in both sulfate solutions in less than $3 \mathrm{yr}$. All cements above $S R 70$ had disintegrated in the $\mathrm{MgSO}_{4}$ solution by the end of the $3-\mathrm{yr}$ period.

On the other hand, there may be noted several types of departure from concordance of results within the several groups. The expansion of specimens in the $\mathrm{MgSO}_{4}$ solution was consistently higher than duplicate specimens in the $\mathrm{Na}_{2} \mathrm{SO}_{4}$ solution. This is because the $\mathrm{Mg}$ ion is converted to difficultly soluble $\mathrm{Mg}(\mathrm{OH})_{2}$, which induces an additional expansion not directly related to that brought about by the $\mathrm{SO}_{4}$ ion [5]. Also, the expansion of the specimens prepared from the high-MgO cements was consistently higher than that of specimens prepared from the low-MgO cements. This illustrates the physical contribution in the sulfate disintegration of mortar specimens due to an agent (periclase) that causes expansion in water alone $[5,16]$. But, as revealed by these tests, the same material has no effect upon the inherent resistivity of the cement to sulfate attack. The total expansion in such cases is a function of the two superimposed effects (1) expansion in water and (2) the chemical interaction with sulfate solutions.

It will be noted further that the specimens within a given group, immersed in the same sulfate solution and prepared from cements of equivalent $\mathrm{MgO}$ content, show a spread in percentage expansions that bears no relation to the sulfate reaction values. Some of these can be explained by compositional differences; others cannot. This would be disturbing to our supposition that such a relation should exist, provided the specimen test were known to produce consistent results. A long experience with that test, however, has shown that uncontrollable factors in the preparation, storage, and measurement of specimens are of such a character that, in every series of tests, unpredictable variations of considerable magnitude may occur. Our difficulty lies in the necessity of using, as a criterion for the adequacy of a new test, an empirical test of admitted inadequacy. The best that can be done in such a case is to observe the highlevel relationships and ignore the relatively insignificant low-level discrepancies. And, as already noted, the agreement between the two tests in the separation of resistant from nonresistant cements is excellent.

\section{Commercial Cements}

The sulfate susceptibility test was applied to the 106 portland cements that were selected by Miller and Manson [13] for comparative studies on sulfata resistivity by various methods. A vast number of data were accumulated by these investigators in collaboration with other laboratories [12], and additional tests on the same cements have been reported by Gause [7].

The sulfate-reaction values of these cements are given in table 3 , together with the calculated potential tricalcium aluminate content and the results of a critical test reported by Miller and Manson [13]. This test shows the percentage of the 5-yr strength of 2 by 4 -in. concrete cylinders stored in tap water that was attained by companion specimens stored for a similar period in Medicine Lake, S. Dak. ${ }^{4}$

TABLE 3. Sulfate reaction values of the Miller and Manson cements [13], together with calculated potential $3 \mathrm{CaO} \cdot \mathrm{Al}_{2} \mathrm{O}_{3}$ contents, and the percentage of normal strength (water storage) retained by 2-by 4 -inch concrete cylinders after 5 years in Medicine Lake

(Arranged in order of increasing sulfate-reaction value)

\begin{tabular}{|c|c|c|c|}
\hline $\begin{array}{c}\text { Cement } \\
\text { No. }\end{array}$ & $\begin{array}{l}\text { Sulfate } \\
\text { reaction } \\
\text { value }\end{array}$ & $\underset{3 \mathrm{CaO} . \mathrm{Al}_{2} \mathrm{O}_{3}}{\text { Potential }}$ & $\begin{array}{l}\text { Percentage } \\
\text { of normal } \\
\text { strength of } \\
\text { 2- by 4-in. } \\
\text { cylinders } \\
\text { after } 5 \text { yrs. in } \\
\text { Medicine } \\
\text { Lake }\end{array}$ \\
\hline $\begin{array}{l}631 \\
507 \\
582 \\
405 \\
513\end{array}$ & $\begin{array}{l}22 \\
28 \\
31 \\
32 \\
33\end{array}$ & $\begin{array}{c}\text { Percent } \\
3 \\
2 \\
5 \\
5 \\
1\end{array}$ & $\begin{array}{c}\text { Percent } \\
92 \\
77 \\
83 \\
79 \\
70\end{array}$ \\
\hline $\begin{array}{l}628 \\
611 \\
543 \\
531 \\
387\end{array}$ & $\begin{array}{l}38 \\
40 \\
44 \\
45 \\
48\end{array}$ & $\begin{array}{l}0 \\
5 \\
4 \\
4 \\
6\end{array}$ & $\begin{array}{l}83 \\
85 \\
67 \\
88 \\
81\end{array}$ \\
\hline $\begin{array}{l}561 \\
393 \\
591 \\
576 \\
426\end{array}$ & $\begin{array}{l}49 \\
49 \\
49 \\
49 \\
50\end{array}$ & $\begin{array}{l}6 \\
4 \\
4 \\
4 \\
4\end{array}$ & $\begin{array}{l}61 \\
63 \\
80 \\
74 \\
69\end{array}$ \\
\hline $\begin{array}{l}441 \\
605 \\
540 \\
564 \\
399\end{array}$ & $\begin{array}{l}51 \\
52 \\
52 \\
53 \\
53\end{array}$ & $\begin{array}{l}7 \\
3 \\
7 \\
6 \\
9\end{array}$ & $\begin{array}{l}30 \\
76 \\
27 \\
32 \\
13\end{array}$ \\
\hline $\begin{array}{l}486 \\
432 \\
381 \\
462 \\
438\end{array}$ & $\begin{array}{l}54 \\
54 \\
55 \\
55 \\
55\end{array}$ & $\begin{array}{l}9 \\
7 \\
4 \\
9 \\
9\end{array}$ & $\begin{array}{r}60 \\
42 \\
86 \\
17 \\
0\end{array}$ \\
\hline $\begin{array}{l}396 \\
489 \\
608 \\
528 \\
384\end{array}$ & $\begin{array}{l}55 \\
5.5 \\
55 \\
55 \\
55\end{array}$ & $\begin{array}{r}5 \\
5 \\
6 \\
7 \\
10\end{array}$ & $\begin{array}{l}39 \\
66 \\
62 \\
52 \\
30\end{array}$ \\
\hline $\begin{array}{l}510 \\
516 \\
414 \\
435 \\
402\end{array}$ & $\begin{array}{l}56 \\
57 \\
58 \\
58 \\
58\end{array}$ & $\begin{array}{r}9 \\
10 \\
10 \\
10 \\
9\end{array}$ & $\begin{array}{r}25 \\
70 \\
16 \\
35 \\
0\end{array}$ \\
\hline $\begin{array}{l}390 \\
453 \\
378 \\
624 \\
621\end{array}$ & $\begin{array}{l}58 \\
58 \\
60 \\
61 \\
62\end{array}$ & $\begin{array}{l}5 \\
7 \\
9 \\
8 \\
3\end{array}$ & $\begin{array}{l}86 \\
16 \\
35 \\
29 \\
63\end{array}$ \\
\hline $\begin{array}{l}596 \\
474 \\
534 \\
619 \\
546\end{array}$ & $\begin{array}{l}62 \\
63 \\
64 \\
64 \\
65\end{array}$ & $\begin{array}{r}7 \\
10 \\
7 \\
10 \\
9\end{array}$ & $\begin{array}{r}68 \\
44 \\
54 \\
0 \\
27\end{array}$ \\
\hline $\begin{array}{l}408 \\
570 \\
549 \\
602 \\
444\end{array}$ & $\begin{array}{l}66 \\
66 \\
67 \\
67 \\
67\end{array}$ & $\begin{array}{r}6 \\
10 \\
9 \\
10 \\
7\end{array}$ & $\begin{array}{r}38 \\
41 \\
0 \\
0 \\
24\end{array}$ \\
\hline $\begin{array}{l}465 \\
644 \\
558 \\
663 \\
650\end{array}$ & $\begin{array}{l}67 \\
67 \\
68 \\
68 \\
68\end{array}$ & $\begin{array}{l}10 \\
10 \\
10 \\
10 \\
11\end{array}$ & $\begin{array}{r}0 \\
0 \\
17 \\
0 \\
0\end{array}$ \\
\hline $\begin{array}{l}450 \\
525 \\
447 \\
579 \\
620\end{array}$ & $\begin{array}{l}68 \\
68 \\
68 \\
68 \\
69\end{array}$ & $\begin{array}{r}6 \\
10 \\
8 \\
12 \\
11\end{array}$ & $\begin{array}{r}0 \\
49 \\
0 \\
0 \\
0\end{array}$ \\
\hline $\begin{array}{l}504 \\
645 \\
537 \\
656 \\
459\end{array}$ & $\begin{array}{l}69 \\
69 \\
70 \\
70 \\
70\end{array}$ & $\begin{array}{r}10 \\
9 \\
10 \\
11 \\
7\end{array}$ & $\begin{array}{l}0 \\
0 \\
0 \\
0 \\
0\end{array}$ \\
\hline
\end{tabular}

4 This lake contained an average of 12 percent of salt, of which two-thirds was $\mathrm{MgSO}_{4}$, one-fourth $\mathrm{Na}_{2} \mathrm{SO}_{4}$, and the remainder a mixture of other salts. 
TABLE 3. Sulfate reaction values of the Miller and Manson cements [13], together with calculated potential $3 \mathrm{CaO} \cdot \mathrm{Al}_{2} \mathrm{O}_{3}$ contents, and the percentage of normal strength (water storage) retainea by 2- by 4-inch concrete cylinders after 5 years in Medicine Lake-Continued

\begin{tabular}{|c|c|c|c|}
\hline $\begin{array}{c}\text { Cement } \\
\text { No. }\end{array}$ & $\begin{array}{l}\text { Sulfate } \\
\text { reaction } \\
\text { value }\end{array}$ & $\underset{3 \mathrm{CaO} \cdot \mathrm{Al}_{2} \mathrm{O}_{3}}{\text { Potential }}$ & $\begin{array}{l}\text { Percentage } \\
\text { of normal } \\
\text { strength of } \\
2 \cdot \text { by 4-in. } \\
\text { cylinders } \\
\text { after } 5 \text { yrs. in } \\
\text { Medicine } \\
\text { Lake }\end{array}$ \\
\hline $\begin{array}{l}423 \\
552 \\
519 \\
471 \\
594\end{array}$ & $\begin{array}{l}70 \\
71 \\
72 \\
74 \\
75\end{array}$ & $\begin{array}{c}\text { Percent } \\
9 \\
8 \\
8 \\
5 \\
13\end{array}$ & $\begin{array}{c}\text { Percent } \\
0 \\
0 \\
48 \\
53 \\
0\end{array}$ \\
\hline $\begin{array}{l}555 \\
477 \\
669 \\
375 \\
495\end{array}$ & $\begin{array}{l}75 \\
76 \\
76 \\
76 \\
77\end{array}$ & $\begin{array}{l}11 \\
12 \\
12 \\
11 \\
10\end{array}$ & $\begin{array}{l}0 \\
0 \\
0 \\
0 \\
0\end{array}$ \\
\hline $\begin{array}{l}641 \\
501 \\
590 \\
614 \\
417\end{array}$ & $\begin{array}{l}78 \\
78 \\
78 \\
78 \\
79\end{array}$ & $\begin{array}{r}10 \\
11 \\
10 \\
9 \\
11\end{array}$ & $\begin{array}{r}0 \\
0 \\
33 \\
8 \\
0\end{array}$ \\
\hline $\begin{array}{l}573 \\
567 \\
629 \\
618 \\
498\end{array}$ & $\begin{array}{l}79 \\
79 \\
80 \\
81 \\
81\end{array}$ & $\begin{array}{r}11 \\
11 \\
12 \\
14 \\
9\end{array}$ & $\begin{array}{r}15 \\
7 \\
0 \\
0 \\
26\end{array}$ \\
\hline $\begin{array}{l}411 \\
492 \\
420 \\
595 \\
372\end{array}$ & $\begin{array}{l}82 \\
84 \\
85 \\
88 \\
89\end{array}$ & $\begin{array}{l}12 \\
10 \\
11 \\
13 \\
13\end{array}$ & $\begin{array}{l}0 \\
0 \\
0 \\
0 \\
0\end{array}$ \\
\hline $\begin{array}{l}468 \\
627 \\
668 \\
480 \\
662\end{array}$ & $\begin{array}{l}90 \\
90 \\
91 \\
92 \\
94\end{array}$ & $\begin{array}{r}12 \\
9 \\
10 \\
13 \\
14\end{array}$ & $\begin{array}{l}0 \\
0 \\
0 \\
0 \\
0\end{array}$ \\
\hline $\begin{array}{l}429 \\
680 \\
630 \\
685 \\
632\end{array}$ & $\begin{array}{l}95 \\
95 \\
96 \\
98 \\
98\end{array}$ & $\begin{array}{l}13 \\
14 \\
11 \\
10 \\
11\end{array}$ & $\begin{array}{l}0 \\
0 \\
0 \\
0 \\
0\end{array}$ \\
\hline $\begin{array}{l}483 \\
456 \\
615 \\
522 \\
593\end{array}$ & $\begin{array}{l}98 \\
98 \\
99 \\
99 \\
99\end{array}$ & $\begin{array}{r}12 \\
7 \\
14 \\
12 \\
14\end{array}$ & $\begin{array}{l}0 \\
0 \\
0 \\
0 \\
0\end{array}$ \\
\hline 599 & 100 & 6 & 0 \\
\hline
\end{tabular}

In figure 1, the sulfate-reaction values are plotted against the percentages of normal strength for these 106 cements. For purposes of differentiation, a specimen was regarded as satisfactory when its percentage of normal strength was 55 or above, and as unsatisfactory when that value fell below 55 . The horizontal line at 55-percent normal strength indicates that separation. It may then be noted that every cement having a sulfate-reaction value below 50 (to the left of the vertical line at 50) has a satisfactory performance record, whereas every cement having a sulfate-reaction value above 63 (to the right of the vertical line at 63) has an unsatisfactory performance record. Of the cements having sulfatereaction values between 50 and 63 , a few have shown a satisfactory performance (above 55 percent of normal strength), and a larger number have not.

It will be noted that, if a curve were to be drawn through the mean positions of the individual values, it would be relatively horizontal in the upper left and lower right sections. In the central area it would be steep. This means that the durability changes slowly with inherent sulfate resistivity when the latter is either high or low, but changes rapidly at intermediate values of sulfate resistivity. It is not to be expected that the correlation will be as good where the rate of change is large.

This relationship may be explained and generalized as follows: As long as the inherent sulfate resistivity of a cement is good, the speciment made from it will have a good durability in sulfate solutions. When that resistivity is poor, the specimens will have a low life expectancy in sulfate solutions. There will, however, be an intermediate range in the sulfate resistivity of a cement (indicated by sulfate reaction values between about 50 and 65 ) wherein the durability of specimens in sulfate solutions will be governed in large measure by other factors. The physical character of the specimen, the care used in its fabrication, or the presence of constituents that

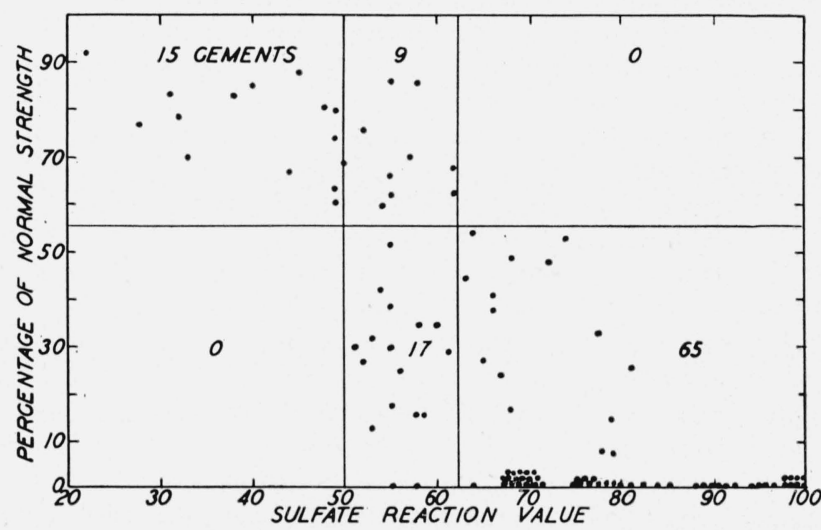

Figure 1. Relation between the sulfate reaction values and the percentage of normal strength (2- by 4-in. concrete cylinders stored in tap water for 5 years) attained by specimens (similar to above at same age) stored in Medicine Lake.

produce changes in structure or composition will be particularly effective within this range.

The comparison was supplemented by a study of the relationships found between the sulfate reaction values and 17 additional tests that have been reported on this series of cements.

These tests were as follows:

1. 2- by 4-in. concrete cylinders having 70 percent or more of "normal" strength after $5 \mathrm{yr}$ in Medicine Lake [Miller 13].

2. Same having 25 percent or more of normal strength after 5 yr in Medicine Lake [13].

3. Same having less than 0.01 -in. expansion after $5 \mathrm{yr}$ in Medicine Lake [13].

4. Same having less than 0.01-in. expansion after 5 yr in 1-percent $\mathrm{Na}_{2} \mathrm{SO}_{4}$ solution [13].

5. 1:5 mortar bars having less than 1.0-percent expansion after $5 \mathrm{yr}$ in 10 -percent $\mathrm{Na}_{2} \mathrm{SO}_{4}$ solution following 3 days' damp curing [Gause 7].

6 . Same having less than 1.0-percent expansion after $1 \mathrm{yr}$ in 10 -percent $\mathrm{Na}_{2} \mathrm{SO}_{4}$ solution following 3 days' damp curing [7]. 
7. Same having less than 1.0-percent expansion after $5 \mathrm{yr}$ in 10 -percent $\mathrm{Na}_{2} \mathrm{SO}_{4}$ solution following 7 days' damp curing [7].

8. Same having less than 1.0-percent expansion after $1 \mathrm{yr}$ in 10 -percent $\mathrm{Na}_{2} \mathrm{SO}_{4}$ solution following 7 days' damp curing [7].

9. 1:5 mortar bars having less than 0.1-percent expansion after 21 days in $0.78 \mathrm{M} \mathrm{Na}_{2} \mathrm{SO}_{4}$ solution [Nat. Bur. Standards 12].

10. Same having less than 1.0-percent expansion after 21 days in $0.78 \mathrm{M} \mathrm{Na}_{2} \mathrm{SO}_{4}$ solution [12].

11. 1:5 mortar bars having less than 0.1-percent expansion after 28 days in $0.50 \mathrm{M} \mathrm{Na}_{2} \mathrm{SO}_{4}$ solution [University Farm 12].

12. Same having less than 1.0-percent expansion after 28 days in $0.50 \mathrm{M} \mathrm{Na}_{2} \mathrm{SO}_{4}$ solution [12].

13. 1:6 mortar bars having less than 0.1-percent expansion after 28 days in $0.15 \mathrm{M} \mathrm{Na}_{2} \mathrm{SO}_{4}$ solution [California Portland Cement Company 12].

14. Same having less than 1.0-percent expansion after 28 days in $0.15 \mathrm{M} \mathrm{Na}_{2} \mathrm{SO}_{4}$ solution [12].

15. 1:6 mortar bars having less than 0.1-percent expansion after 28 days in $0.15 \mathrm{M} \mathrm{Na}_{2} \mathrm{SO}_{4}$ solution [Portland Cement Association 12].

16. Same having less than 1.0-percent expansion after 28 days in $0.15 \mathrm{M} \mathrm{Na}_{2} \mathrm{SO}_{4}$ solution [12].

17. Same having sonic change greater than +1 after 28 days in $0.15 \mathrm{M} \mathrm{Na}_{2} \mathrm{SO}_{4}$ solution [12].

Cements that passed all of these tests were given ratings of 17 ; those that passed none of them received ratings of 0 ; the ratings given to other cements were the number of tests that they passed. Such a classification is arbitrary but has the advantage of cancelling discrepancies that are due to the various anomalous effects as described earlier.

For purposes of comparison, a cement having a rating of 14 or above is considered as having excellent sulfate resistance, one having a rating between 13 and 8 as iair, and one having a rating of 7 or less as poor. When the results of this composite test were plotted against sulfate reaction value, the diagram shown in figure 2 was obtained. It will be observed that 15 cements have reaction values of 50 or less, all but one of which are rated as excellent. Sixty-one cements have reaction values of 65 or more, only two

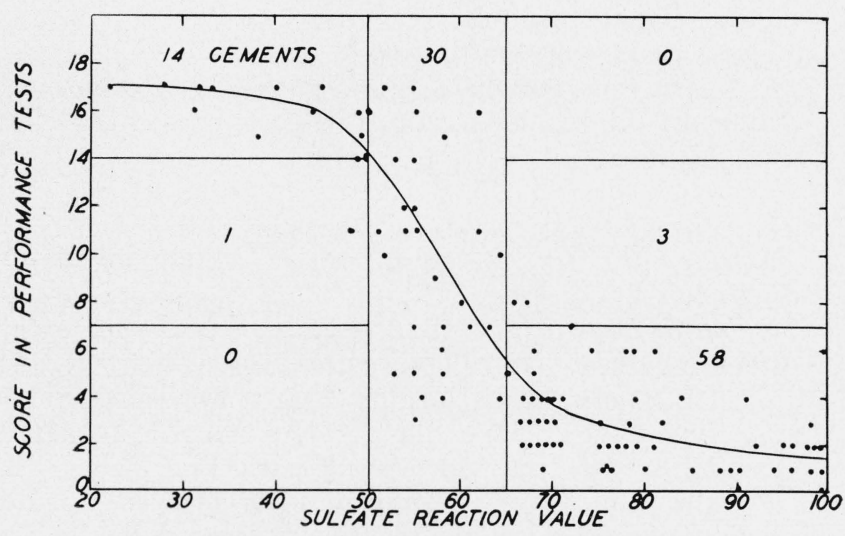

Figure 2. Comparison of reaction values with ratings of the Miller cements based on 17 performance requirements. of which attain a fair rating. Between the reaction values of 50 and 65 , the spread is wide. This confirms the results already presented that a sulfate reaction value up to 50 indicates a sulfate-resistant cement; above 65 a nonsulfate-resistant cement; and that cements having sulfate reaction values between 50 and 65 are in a critical position where other factors of composition, fabrication, etc., may greatly affect the durability of specimens or structures in sulfate exposures.

It may be pointed out that the establishment of sulfate resistivity from computed tricalcium aluminate content is subject to certain inherent errors. Statistically the relationship is good but lacks assurance of accuracy. The reasons are: 1, that the calculation of potential tricalcium aluminate gives no indication of the relative amounts of that material or of the alumina-iron solid solution that are in the crystalline and the glassy states (for, as pointed out earlier, the sulfate resistivity of the cement differs with the state of those materials) and, 2 , recent investigations by Swayze [14] have indicated that the usual bases for the computation of tricalcium aluminate are subject to correction due to the ironphase solid solution.

\section{Conclusions}

From a consideration of the correlations as above reported, it appears that the sulfate susceptibility test may be useful as an index of the inherent resistivity of cements to attack by sulfate solutions. Since this chemical attack is very largely associated with the formation of calcium sulfoaluminate by interaction between the sulfate and aluminate in saturated limewater, a measurement of that reaction may be expected to reveal the intrinsic sulfate reactivity of the cement.

It should be emphasized that this test does not indicate the resistivity that may be induced in a concrete or mortar specimen by any physical means, such as change in density, permeability, air entrainment, etc. Nor does it indicate the life of specimens in sulfate solutions, insofar as that life is affected by the presence of constituents in the cement (as periclase) or in the aggregate (as reactive siliceous materials) that may interact expansively quite irrespective of the sulfate reaction.

By correlations made with performance tests, it is concluded that:

1. A cement having a sulfate reaction value up to 50 may be considered as relatively resistant to sulfate attack; the lower that value, the greater the resistivity of the cement. Concrete or mortar structures made with such a cement may be expected to have a satisfactory durability when exposed to sulfate waters, except as factors other than sulfata reaction may be involved in disintegrative forces.

2 . A cement having a sulfate reaction value between 50 and 65 should be regarded with apprehension insofar as its sulfate resistivity is concerned. Concrete or mortar structures made with such a cement may be durable, in sulfate exposures, if they 
are dense and impermeable, and are free of other disintegrative agents. In this range of cements, airentrainment would undoubtedly be beneficial, and good workmanship would be absolutely necessary.

3. A cement having a sulfate reaction value of over 65 should be considered as relatively nonresistant to sulfate attack; the higher that value, the lower the resistivity of the cement. Concrete or mortar structures made with such a cement may be expected to have a relatively short life when exposed to sulfate waters, regardless of the quality of the workmanship or the presence of beneficial agents.

The authors take pleasure in acknowledging the contribution of I. C. Bechtold in the development of the sulfate susceptibility test, and the assistance of A. C. Bonanno, E. G. Siggers, and C. Pinkerton in numerous analyses and tests.

\section{References}

[1] Am. Soc. Testing Materials, Standard methods of chemical analysis of portland cement, C 114-47.

[2] P. H. Bates, A. J. Phillips, and R. J. Wig, Tech. Pap. BS 2, 7 (1912) T12.
[3] R. H. Gogue, Chemistry of portland cement, pp. 508 to 520 (Reinhold Pub. Co., New York, N. Y., 1947).

[4] R. H. Bogue, Studies on the volume stability of portland cement pastes, privately printed by the Portland Cement Association Fellowship, PCAF Paper 55 (1949).

[5] R. H. Bogue, Wm. Lerch, and W. C. Taylor, Ind. Eng. Chem. 26, 1049 (1934); PCAF Paper 28.

[6] F. K. Cameron and J. W. Bell, U. S. Dept. Agr. Bul. 23, 47 (1906)

[7] G R. Gause, Am. Soc. Testing Materials Bul. 112, 17 (1941).

[8] W. C. Hansen and E. E. Pressler, Ind. Eng. Chem. 39, 1280 (1947)

[9] W. C. Hansen, personal communication.

[10] Wm. Lerch, Proc. Am. Soc. Testing Materials 46, 1252 (1946).

[11] Wm. Lerch, F. W. Ashton, and R. H. Bogue, BS J. Research 2, 715 (1929) RP54; PCAF Paper 19.

[12] D. G. Miller, Report of Working Committee on Sulfate Resistance, Com. C-1, ASTM (July 1943).

[13] D. G. Miller and P. W. Manson, U. S. Dept. Agr. Bul. 358; Proc. Am. Soc. Testing Materials 40, 988 (1940).

[14] M. A. Swayze, Am. J. Sci. 244, 1, 65 (1946).

[15] T. Thorvaldson, R. H. Harris, and D. Wolochow, Ind. Eng. Chem. 17, 467 (1925).

[16] A. H. White and H. S. Kemp, Concrete 51, 105 (1943).

Washington, June 17, 1949.

\title{
Cascade-Connected Attenuators
}

\author{
By Robert W. Beatty
}

\begin{abstract}
A method is presented for evaluating the error obtained when the attenuation of a number of cascade-connected attenuators is determined by adding the attenuation of each unit. The error is caused by mismatches at the attenuator junctions and is expressed in terms of reflection coefficients measured at the junctions. The analysis is pertinent to the case in which individual calibrated attenuators are available, but it is not feasible or possible to calibrate the combination of two or more attenuators. A nomogram is drawn that shows the limits of error (for two cascaded attenuators) in terms of voltage standing-wave ratios. Inspection of the nomogram shows that the error for typical UHF and microwave attenuators is generally of the same order of magnitude as the calibration errors.
\end{abstract}

\section{Introduction}

In order to obtain a desired attenuation, it is often necessary to connect two or more calibrated attenuators in series (cascade). Cascade-connected attenuators are used as "gage blocks" to extend the range of power meters without appreciable loss of accuracy. ${ }^{1}$ Fixed and variable attenuators are cascade-connected in order to obtain increased range.

The attenuation of such combinations could be obtained by accurate measurement (calibration), but this is not feasible or possible in many cases because attenuator calibration equipment is not widely available.

The total attenuation of cascade-connected attenuators is usually obtained by adding the attenuation

1 C. G. Montgomery, Technique of microwave measurements, p. 835 (McGrawHill Book, Co., Inc., New York, N. Y., 1947). of each unit. If mismatch exists at the attenuator junctions, the attenuation obtained by this method is incorrect. The resulting error is a function of the amount of mismatch and may be evaluated in terms of the reflection coefficients measured at the attenuator junctions.

\section{Analysis}

In the following analysis, UHF or microwave attenuators are considered. It is assumed that the individual attenuators have been calibrated in a transmission-line system having the same characteristic impedance $\left(\dot{Z}_{0}\right)$ and critical dimensions as the system in which the attenuators are to be used. A further requirement is that the attenuators are passive linear four-terminal networks having terminals that permit connection to the transmissionline system without discontinuity. 